\title{
PENERAPAN KONSEP BUDAYA NEW NORMAL PADA RUANG KANTOR PELAYANAN
}

\author{
Siti Indah Lestari, Muhammad Zulfikri Hadi \\ Prodi Desain Interior \\ Fakultas Seni dan Desain Universitas Potensi Utama Medan \\ Indah.ayangjelek@gmail.com,zulfikrihadii@gmail.com
}

\begin{abstract}
ABSTRAK
Desain Interior pada kantor merupakan salah satu poin penting dalam pembentuk dan membangun citra dari suatu instansi. Kantor yang interiornya tidak tertata dengan baik pastinya akan memberi suasana kurang nyaman kepada para pegawai bahkan berdampak juga terhadap kesan pengunjung dan berasumsi bahwasanya kinerja kantor itu tidak jauh beda dengan tampilan tata ruangnya. Oleh karena itu, penataan ruang pada sebuah kantor tidak hanya bertujuan agar para pekerja nya nyaman menjalankan pekerjaan, namun juga mampu menampilkan citra diri perusahaan tersebut.

Di masa pandemi saat ini kantor yang nyaman adalah tempat yang paling di cari oleh semua pihak yang berada di dalamnya baik pegawai maupun pengunjung yang datang. Sebab di masa pandemi seluruh kegiatan wajib memenuhi protokol kesehatan yang di tetapkan oleh pemerintah. Penelitian ini dilakukan di kantor administrasi dosen Universitas Potensi Utama, dimana kantor administrasi ini sehari-hari melakukan pelayanan terhadap dosen dan mahasiswa. Untuk itu tujuan penelitian ini memberikan masukan kepada pemilik Universitas untuk dapat menerapkan desain kantor pelayanan dengan menerapkan protokol kesehatan pada saat kegiatan new normal nantinya.

Konsep budaya new normal dengan pendekatan futuristic diharapkan mampu mendukung kegiatan administrasi saat pelayanan aktif kembali sehingga tidak ada rasa takut dan cemas untuk bertatap muka oleh orang-orang yang ada di lingkungan tersebut serta dapat meningkatkan gairah para pekerjanya. Pelengkap interior serta peralatan kerja juga dipilih menyesuaikan kebutuhan para pekerja serta fungsionalitasnya.
\end{abstract}

Kata kunci: Desain, Interior, desain kantor

\begin{abstract}
Interior design in offices is one of the important points in shaping and building the image of an agency. An office whose interior is not properly organized will certainly give employees an uncomfortable atmosphere and even have an impact on the impression of visitors and maybe it is possible to assume that the performance of the office may not be much different from theappearance of the layout. Therefore, spatial planning in an office is not only intended for workers to be comfortable doing work, but also able to present the company's selft-image.

During the current pandemic, a comfortable office is the place most sought after by all parties in it, both employees and visitors who come. Because during a pandemic, all activities are required to comply with the health protocol set by the government. This research was conducted in the administrative office of the lecturers of the Main Potential University, where this administration office provides daily services to lecturers and students. For this reason, the purpose of this study is to provide input to University owners to be able to implement the service office design by implementing health protocols during new normal activities later.
\end{abstract}


The concept of a new normal culture with a futuristic approach is expected to be able to support administrative activities when services are active again so that there is no fear and anxiety to meet face to face by people in the environment and can increase the passion of the workers. Interior fittings and work equipment are also chosen to suit the needs of the workers and their functionality.

Keywords: Design, interior, office design

\section{PENDAHULUAN}

Desain Interior pada kantor merupakan salah satu poin penting dalam pembentuk dan pembangun citra dari suatu instansi. Kantor yang interiornya tidak tertata dengan baik pastinya akan berdampak terhadap suasana bagi para pegawai dan membentuk rasa jenuh, kenyamanan dari desain interior tentunya memberi pengaruh positif dan keberlangsungan kerja para pegawai. Penataan ruang kantor juga tidak semata-mata untuk tujuan agar para pekerja merasa nyaman sehingga produktifitas kerja pun dapat meningkat, namun juga penataan ruangan kantor dapat merepresentasikan citra dari instansi.

Ruangan kantor yang nyaman dan aman tentunya ialah ruangan yang memberi pengaruh positif bagi setiap orang dalam instansi tersebut, baik itu pegawai maupun pengunjung. Segala aspek harus diperkirakan mulai dari peralatan kantor maupun furniture pada ruangan sebaiknya dipilih sesuai dengan kebutuhan sehingga tidak menyia-nyiakan kondisi ruangan.

Melihat pada kondisi ruangan kantor Administrasi Dosen Gedung B yang sangat jauh dari kata estetis dan kurang mengoptimalkan setiap sudut ruangan nya yang menjadikan ruangan kantor Adm. Dosen Gedung B terlihat tidak ideal. Terlebih pada masa pandemic sekarang serta keadaan maupun suasana interior pada ruang kantor yang kaku dan tidak menggambarkan identitas instansi yang bisa dikatakan instansi dikenal dengan program pengajaran yang terbilang unggul di bidang teknologi dan komputerisasi. Maka dari itu perlu dilakukan re-design pada interior kantor Adm. Dosen dimana penekanan desain di titik beratkan pada desain yang dapat mengakomodasi aktifitas yang berlangsung di area ruangan, membangun produktifitas serta kenyamanan bagi para pegawai maupun pengunjung, dan fasilitas keamaanan merujuk pada kondisi pandemic covid-19.

Melihat keadaan pandemic penyesuaian pola hidup yang sebelum nya menjadi pola hidup New Normal mengharuskan individu maupun lingkungan menyesuaikan keadaan terlebih kantor Administrasi Dosen Gedung B bisa dikatakan sebagai ruang publik dimana banyak aktifitas yang berlangsung pada ruang tersebut, sehingga diharapkan lingkungan dimana aktifitas itu berlangsung dapat mengakomodasi segala kegiatan dan menjamin keamanan setiap individu dari penyebaran virus di masa pandemic ini dengan membuat fasilitas-fasilitas yang mendukung keberlangsungan pola hidup New Normal.

Pada penelitian ini menerapkan pendekatan konsep yang mendukung terlaksananya konsep New Normal yakni pendekatan konsep futuristik dimana konsep ini dinilai mampu memecahkan masalah yang ada di kantor administrasi dosen sehingga dapat dirumuskan ke dalam bentuk abstrak dan menjadi landasan untuk penerapan desain ke dalam wujud nyata.

\section{STUDI LITERATUR}

Kantor merupakan suatu gedung atau bagian dari gedung yang pemakaian utama atau satu - satunya sebagai suatu kantor atau untuk tujuan - tujuan perkantoran seperti keperluan administrasi, pekerjaan tulisan, pengurusan uang dan kegiatan telepon. (Hayatullah, 2010)

Rancangan adalah sesuatu yang sudah dirancang dari proses merancang (perencanaan) guna mencapai tujuan yang ditetapkan dalam pelaksanaan peletakan. Ergonomi adalah penyerasian antara user, kegiatan, dan lingkungan dimana mengkalkulasi 
dan memperhitungkan segala aspek seperti ukuran, objektivitas, dan fleksibilitas dengan tujuan mendapatkan kenyamanan dan keamaan bagi penghuni (user) ruangan. Penghuni (user) adalah orang atau sekelompok orang yang mendiami suatu kediaman.

\section{A. DESAIN INTERIOR}

Desain interior adalah merancang menata dan merencanakan tata letak dalam sebuah ruangan. Tatanan fisik suatu ruang interior dapat memenuhi kebutuhan dasar manusia akan sarana untuk bernanung dan berlindung; menentukkan langkah sekaligus mengatur berbagai bentuk aktivitas ; memelihara aspirasi kita dan mengekspresikan ide - ide yang menyertai segala tindakan kita.

Kantor berasal dari bahasa Belanda kantor adalah sebutan untuk tempat yang digunakan untuk perniagaan atau perusahaan yang dijalankan secara rutin. Kantor bisa hanya berupa suatu kamar atau ruangan kecil maupun bangunan bertingkat tinggi.

\section{B. ASPEK BANGUNAN}

Perencangan bangunan dan interior secara optimal menurut Darmono dalam Sukesi (2009: 12-13), terdapat aspek-aspek yang dapat menunjang aktifitas users sebagai berikut:

1. Aspek Fungsional

Penataan interior harus mampu mendukung kegiatan pegawai secara keseluruhan baik pegawai maupun pengunjung di area kantor tersebut serta penataan interior dapat tercipta secara optimal.

2. Aspek Psikologi Pengguna

Bertujuan agar pegawai yang berada di area kantor merasa nyaman dan tenang serta leluasa bergerak di dalam ruang tersebut.

3. Aspek Estetika

Penataan interior yang indah, serasa, bersih dan terang tanpa mengindahkan

faktor fungsionalnya dapat mempengaruhi kenyamanan para pegawai yang bekerja.

4. Aspek Keamanan

Keamanan kondisi ruang dan berbagai furniture yang berkaitan dengan material juga harus diperhitungkan, demi menjaga kualitas dari bangunan dan furniture dengan baik, agar terhindar dari kecelakaan saat berada didalam ruang disebabkan oleh material dari furniture itu sendiri maupun kondisi fisik bangunan yang tidak aman ditambah melihat kondisi pandemic covid-19 keamanan ruang maupun pegawai harus di fokus kan agar terhindar dari wabah pandemic.

\section{PENDEKATAN DESAIN FUTURISTIC}

Konsep desain futuristic adalah konsep desain yang merujuk pada masa depan yang terbentuk dari kata future dalam Bahasa inggris yang berarti masa depan, desain futuristic sendiri memiliki ciri desain yang khas/ kuat, bentuk yang tajam (bersudut), mengaplikasikan material yang merujuk fungsionalitas, dinamis dimana terbilang lazim dari konsep desain yang sering di terapkan. Konsep futuristic sendiri di pilih dengan tujuan dapat membangun citra instansi yang dikenal dikalangan masyarakat dengan keunggulan di bidang teknologi serta komputerisasi, melihat hal tersebut konsep desain futuristic dirasa sangat cocok untuk di terapkan pada rancangan ulang ruang kantor.

Ide konsep dari desain futuristic sendiri berangkat dari adanya keinginan menciptakan suasana baru pada ruangan kantor dan menghilangkan kesan desain yang monoton. Interior futuristic adalah interior yang di desain dengan bentuk unik dan berorientasi pada masa depan dan juga ketidak laziman. Bentukan pada desain futuristic sendiri biasanya berbentuk bulat, kotak, tidak beraturan atau berbentuk seperti badan hewan. Pada 
perancangan ini pengkarya menggunakan warna mayoritas putih dengan aksen biru karena warna biru sendiri merupakan warna yang diterapkan pada logo instansi sehingga cocok diaplikasikan pada perancangan desain ini.

Merujuk pada keadaan pandemic yang belum juga usai, dimana diharuskan nya menerapkan pola hidup New Normal dimana tempat ataupun ruang public di harap dapat menyesuaikan kondisi lingkungan yang mendukung serta aman bagi setiap orang yang beraktifitas di ruang tersebut terjamin dan terakomodasi setiap kegiatan yang dilakukan di ruang tersebut. New Normal sendiri dimana setiap individu diharuskan dapat hidup berdampingan dengan keadaan pandemic tentunya dengan menerapkan pola hidup dan kebiasaan yang berbeda dari sebelum nya, seperti memakai perlindungan diri seperti masker, face shield, dll. Menjaga jarak fisik, Menjaga kebersihan dengan rutin mencuci tangan, serta mengkontrol emosi di ruang public agar tidak panik sehingga imunitas tetap terjaga.

Konsep Futuristic dalam keadaan pandemic atau pola hidup New Normal sendiri sebenarnya tidak terlalu merubah konsep futuristic ini sendiri, bisa dikatakan dengan penyesuaian pola New Normal tersebut terhadap konsep desain Futuristic hanya menambah beberapa elemen / fasilitas yang dapat mendukung keberlangsungan aktifitas setiap individu dalam menerapkan pola hidup New Normal. Hanya saja penambahan elemen/ fasilitas yang mendukung keamanan dan pencegahan penyebaran virus seperti penyediaan hand sanitizer, pengaplikasian sekat akrilik, penyediaan fasilitas kebersihan, serta penataan furniture, zoning, dan lain-lain disesuaikan dengan konsep desain futuristic agar semua elemen tambahan tetap berkesinambungan dengan semua aspek dalam ruang dan desain yang telah direncanakan.

Ciri dari konsep desain Futuristic adalah:

1. Desain Minimalis Berkelas

Konsep dari desain futuristic yang minimalis berkelas disebabkan konsep ini masih banyak memakai prinsip-prinsip dari desain minimalis dalam penataan ruang, ruang bergaya futuristic tidak terlalu menggunakan benda-benda dekortif serta bentuk furniture nya pun sangat simple dan hanya mengaplikasikan furniture yang esnsial seperti furniture yang benar-benar diperlukan di ruangan tersebut

2. Bentuk Lengkung Dominan

Dalam konsep desain futuristic tidak jarang masih ditemukan bentuk-bentuk geometris pada hasil desain. Namun, secara keseluruhan bentuk dominan yang mencakup lebih banyak isi ruang ialah bentuk lengkung atau modular. Hal tersebut dapat dilihat pada struktur bangunan di dalam ruangan yang berkonsep futuristic seperti pada bagian plafon maupun dinding ruangan.

3. Perpaduan Warna Kontras dan Lampu LED

Konsep futuristic tak bisa lepas dari lampu-lampu LED yang sangateramat mencirikan konsep ini, pengaplikasian lampu LED juga terbilang flexible sebab bisa diterapkan di segala struktur interior seperti plafon, dinding, maupun lantai. Terlebih perpaduan warna kontras seperti warna yang akan di aplikasikan pada rancangan desain ini ialah warna dominan putih dengan aksen biru pada beberapa bagian ruang serta warna lampu LED nya yang akan menonjolkan konsep dari desain futuristic ini.

Desain interior pada ruang kerja seperti kantor mempunyai peran yang sangat penting dalam memberikan suasan yang nyaman pada para pegawai yang beraktifitas, dimana perasaan nyaman serta kepuasan pengguna ruangan akan meningkatkan efektifitas serta kreatifitas para pekerja didalamnya. Pemilihan furniture dan pewarnaan ruang yang tepat serta praktis akan membuat pekerja merasakan suasana yang nyaman untuk bekerja. Kepuasan serta rasa nyaman itu akan diperoleh apabila unsur desain interior saling 
mendukung untuk menciptakan suasana yang nyaman pada setiap ruangan dan meningkatkan efisiensi serta efektifitas pekerja dalam melakukan aktifitas nya.

Pada kantor Administrasi Dosen ini segala aspek harus di pertimbangkan, mulai dari pemilihan furniture yang sesuai pada ruang kerja dan ruang lainya, seperti tempat duduk dan meja, serta prosedur keamaanan dalam mencegah penyebaran wabah pandemic covid-19 dengan contoh memberlakukan nya social distancing dengan diberi nya symbol, menyediakan fasilitas kebersihan, dan memberi sekat akrilik pada meja pegawai. Pengaturan space untuk berlalu lalang juga harus di pertimbangkan serta penerapan blocking agar para penghuni di dalam area kantor leluasa untuk bergerak.

Dengan mengusung konsep desain futuristic pada perencanaan re-design ruang kantor Administrasi Dosen Gedung B Universitas Potensi Utama yang berfokus pada pembangunan keselarasan citra instansi melalui desain ruangan kantor Adminitrasi Dosen, fungsionalitas ruangan kantor, pembangunan suasana kerja para pegawai melalui hasil terapan desain yang ditujukan memberi suasana nyaman dan aman untuk para pegawai yang beraktifitas.

\section{PEMBAHASAN}

\subsection{Analisis Data}

Setelah semua data terkumpul peneliti akan memasuki tahap analisis data, dimana analisis data bertujuan untuk menjawab permasalahan yang ada dalam penelitian.

\section{Desain kantor sebelumnya}

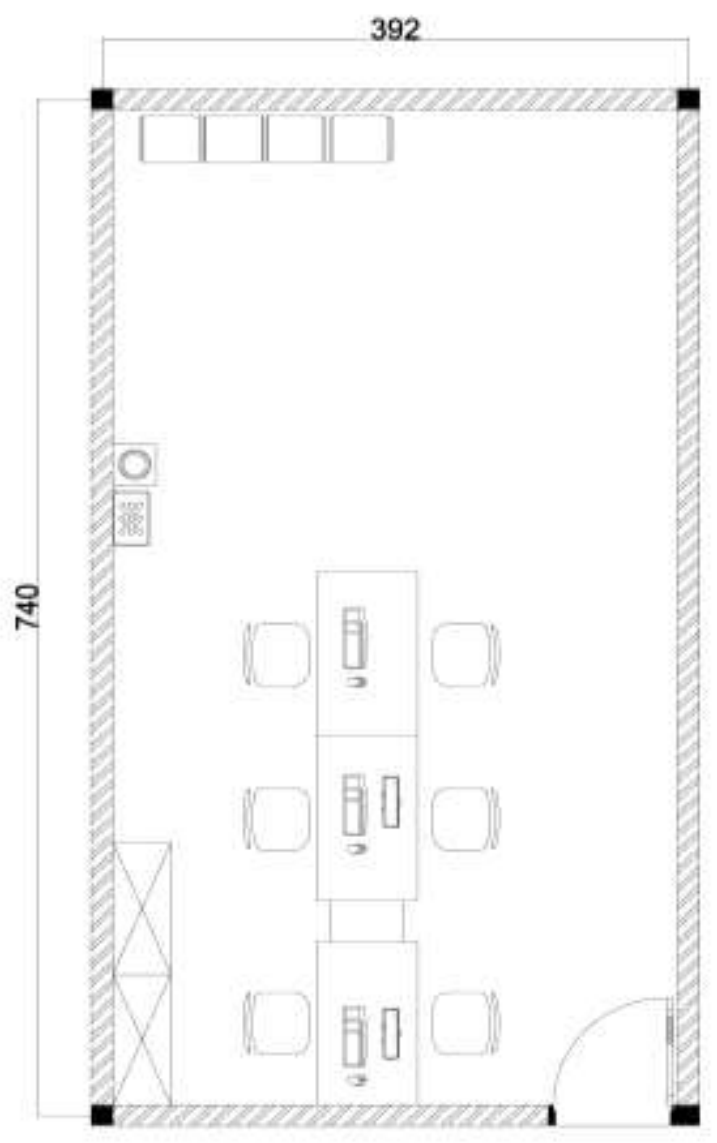

Gambar 1. Layout Awal Ruangan Administrasi Dosen Gedung B 


\section{Kekurangan pada Desain awal ruang Administrasi Dosen Gedung B adalah:}

1.Penempatan area kurang terbaca.

2.Ruangan terlihat monoton dan zoning kurang menarik.

3.Beberapa bagian ruangan tidak di maksimalkan.

4.Pemilihan material pada furniture terkesan biasa.

5.Ruangan tunggu bagi para dosen hanya pada satu area.

6.Ruangan tertutup dan tidak ada bias cahaya alami yang membantu penerangan ruangan.

7.Kondisi ruangan pada Layout tidak memberi kemudahan dalam pencegahan penularan virus di masa pandemic.

8. Kurang merepresentasikan citra instansi.

\section{LayOut Desain Kantor Adm. Dosen Setelah di Desain}

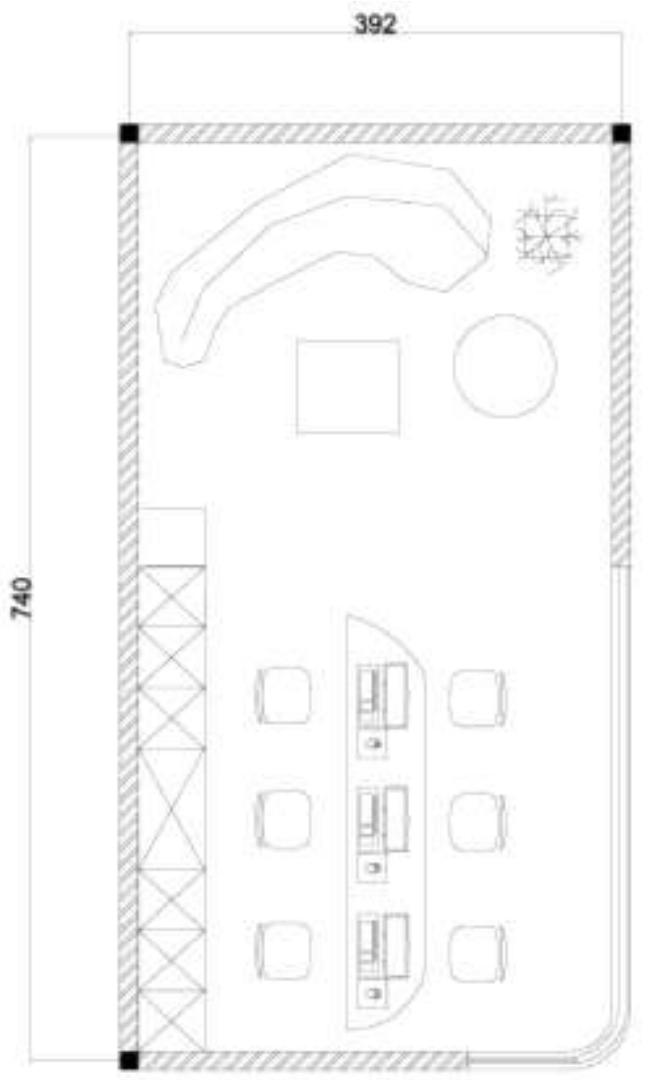

Gambar 2. Layout Re-Desain Ruangan Administrasi Dosen Gedung B

\section{Kelebihan pada Desain Administrasi Dosen Gedung B setelah di re-desain adalah:}

1.Penempatan area lebih terbaca.

2.Ruangan terlihat lebih menarik.

3.Bagian pada ruangan lebih termaksimalkan dari sebelum nya.

4.Pengaplikasian material pada furniture selaras namun memliki variasi membuat ruangan lebih hidup.

5.Area tunggu bagi para dosen lebih menarik.

6.Ruangan yang sebagian menggunakan kaca pada area dinding memberi akses pada bias cahaya untuk masuk, sehingga pada hari cerah penggunaan listrik bisa di minimalisir.

7.Kondisi ruangan menyesuaikan pada masa pandemic dan tersediakan nya fasilitas pencegahan penularan yang mudah diakses. 
8. Merepresentasikan citra instansi yang dikenal baik dalam bidang computer dan teknologi.

\subsection{Pembahasan}

1. Tata Ruangnya Sudah Baik

Tata ruang baik sirkulasi dan zoning pada ruang Adm. Dosen Gedung B lebih terorganisir sehingga lebih bisa terbaca bagi para pengunjung baik dosen dan mahasiswa.

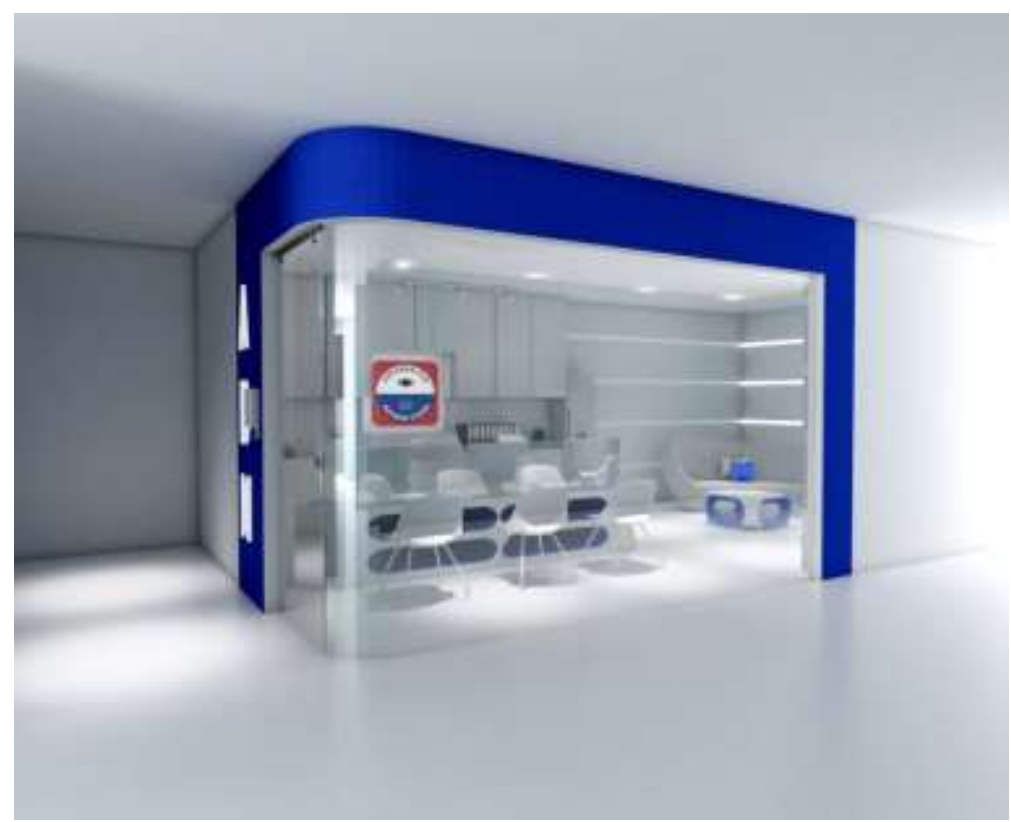

Gambar 3. Visualisasi Digital Administrasi Dosen Gedung B Universitas Potensi Utama

2. Tata Warna Sudah Baik

Tata warna yang menyesuaikan dengan warna instansi tentunya mereresentasikan instansi dengan harapan memberi citra baik untuk instansi, warna-warna yang disusun dengan baik dipadu dengan material yang berbeda pada tiap sudut ruangan memberi kesan lebih hidup.

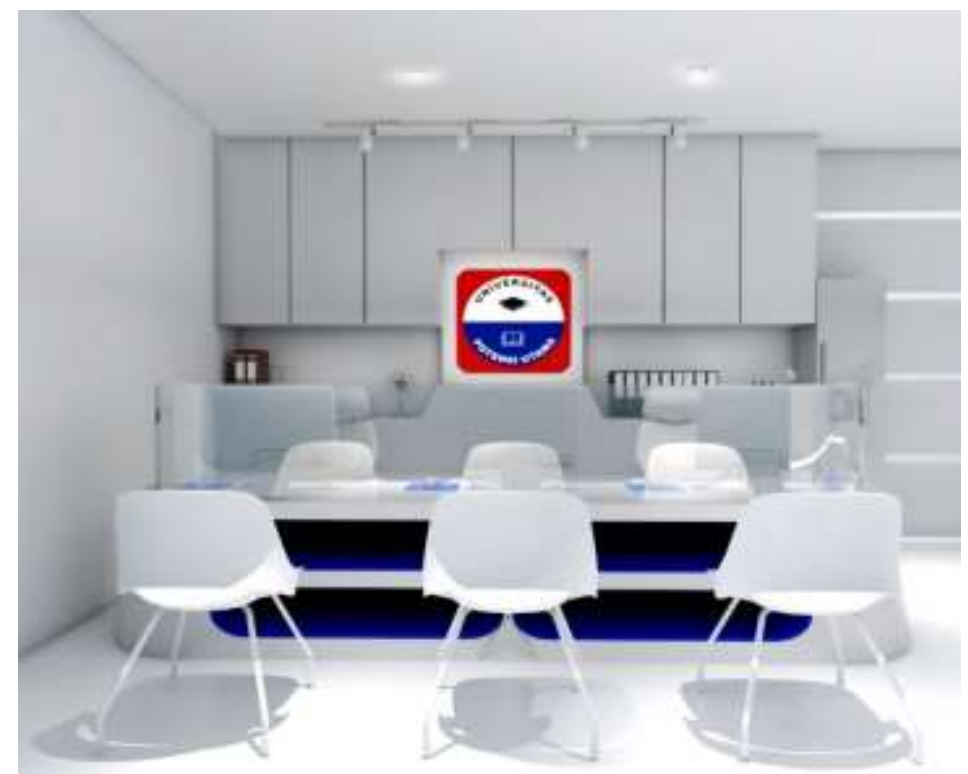

Gambar 4. Visualisasi Digital Meja Administrasi Dosen Gedung B 
3. Tata Pencahayaan Sudah Baik

Pencahayaan tentunya terbantu dengan bias cahaya yang masuk melalui bagian dinding yang menggunakan material kaca, ruangan yang dominan putih pun dengan sangat baik merefleksikan sinar dari lampu sehingga pencahyaan pada ruangan Adm.Dosen Gedung B terbilang sangat baik.

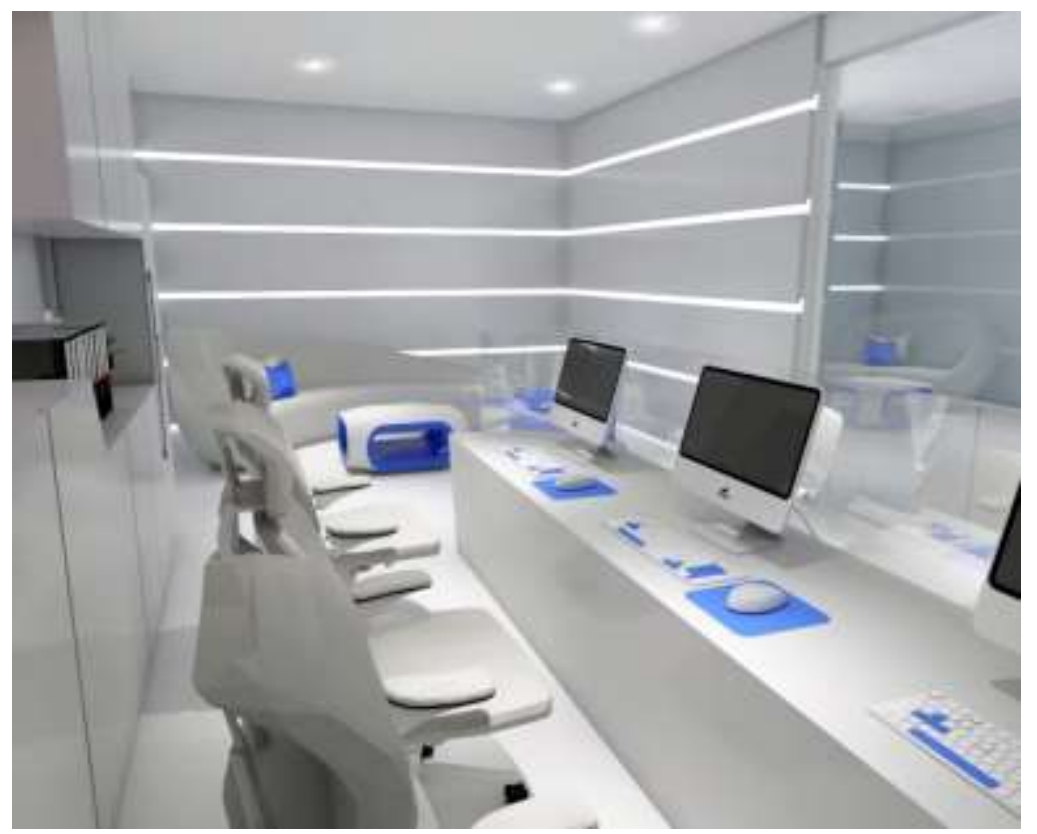

Gambar 5. Visualisasi Digital Ruangan Administrasi Dosen Gedung B

\section{Ruangan Bersih}

Ruangan yang dominan warna putih tentunya memberi kesan bersih nan luas, kombinasi dengan warna biru yang memberi kesan sejuk memberi suasana lebih nyaman pada ruangan.

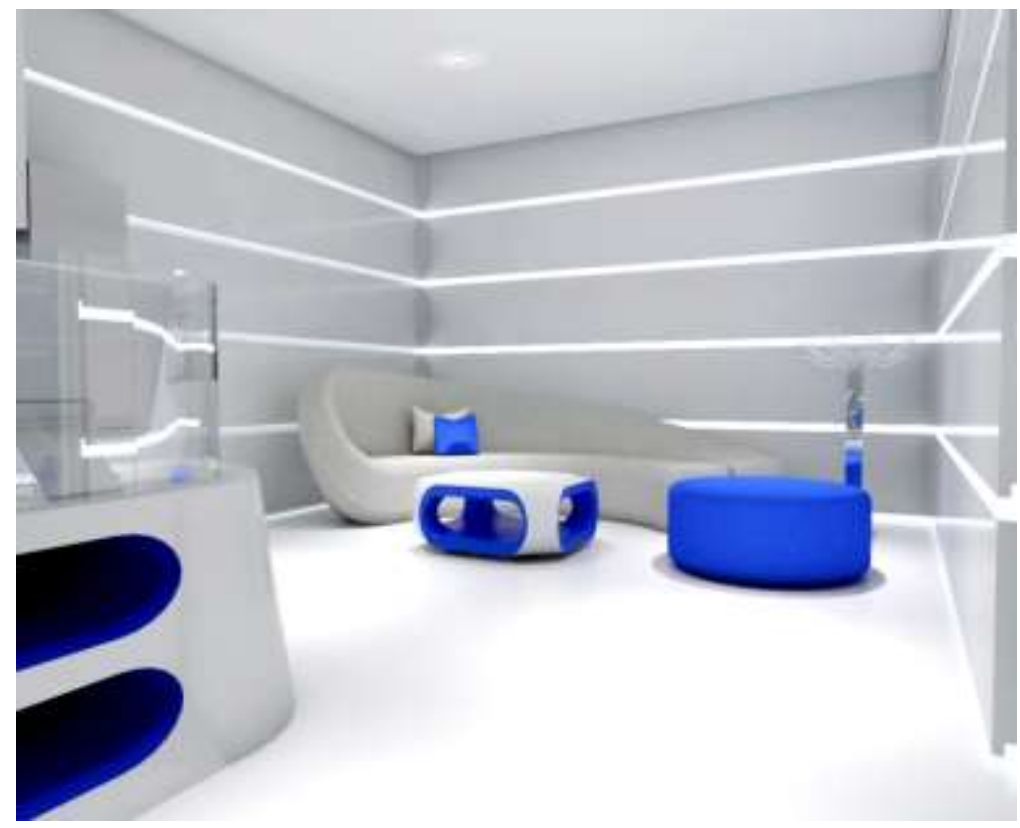

Gambar 6. Visualisasi Digital Area Tunggu Administrasi Dosen Gedung B 
5. Ruangan Tidak Sempit

Pengaplikasian warna dominan putih dan kaca pada sebagian dinding dan pintu masuk memberi ilusi ruangan lebih luas.

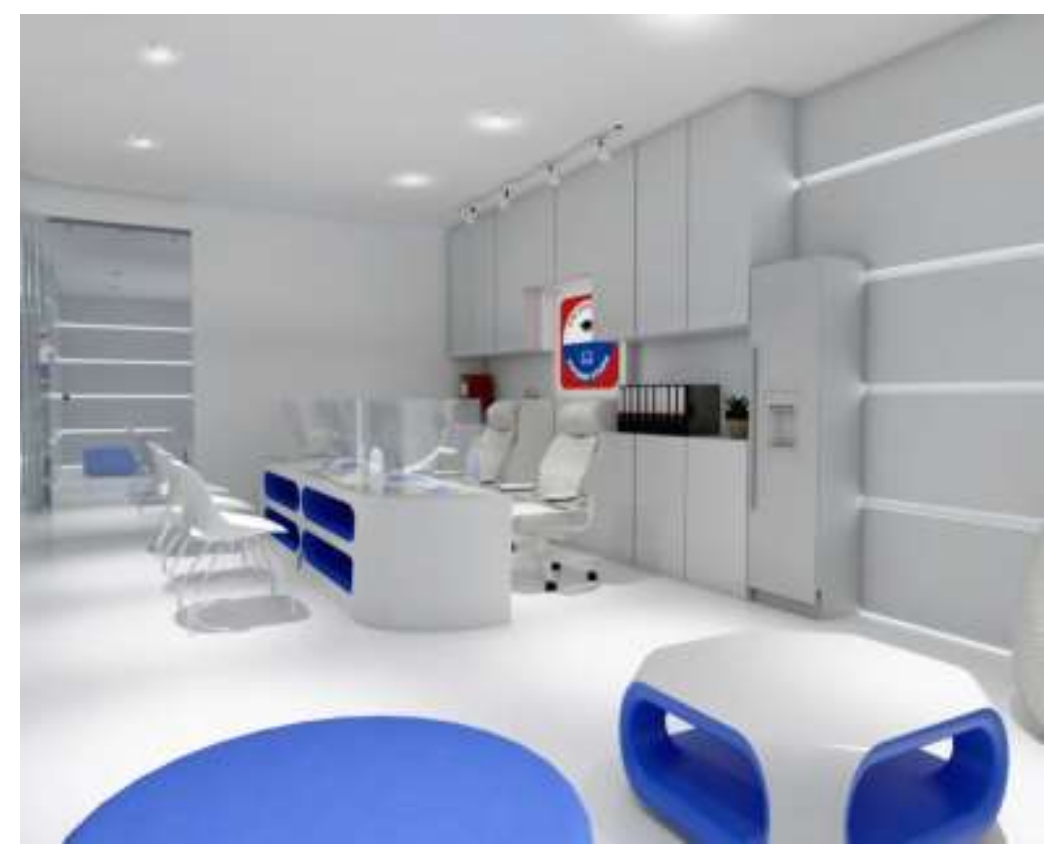

Gambar 7. Visualisasi Digital Perspektif Ruangan Administrasi Dosen Gedung B

1. Mendukung pencegahan pandemic

Desain ini juga menyesuaikan dengan apa yang terjadi saat ini, dengan mempermudah kebutuhan untuk mencegah dara proses penularan virus di masa pandemic disediakan nya hand sanitizer pada dinding yang berdekatan dengan akses masuk ke dalam ruangan, memberi sekat pada meja pegawai yang bertujuan mencegah proses penularan serta menjaga keamanan pegawai dan pengunjung saat beraktifitas.

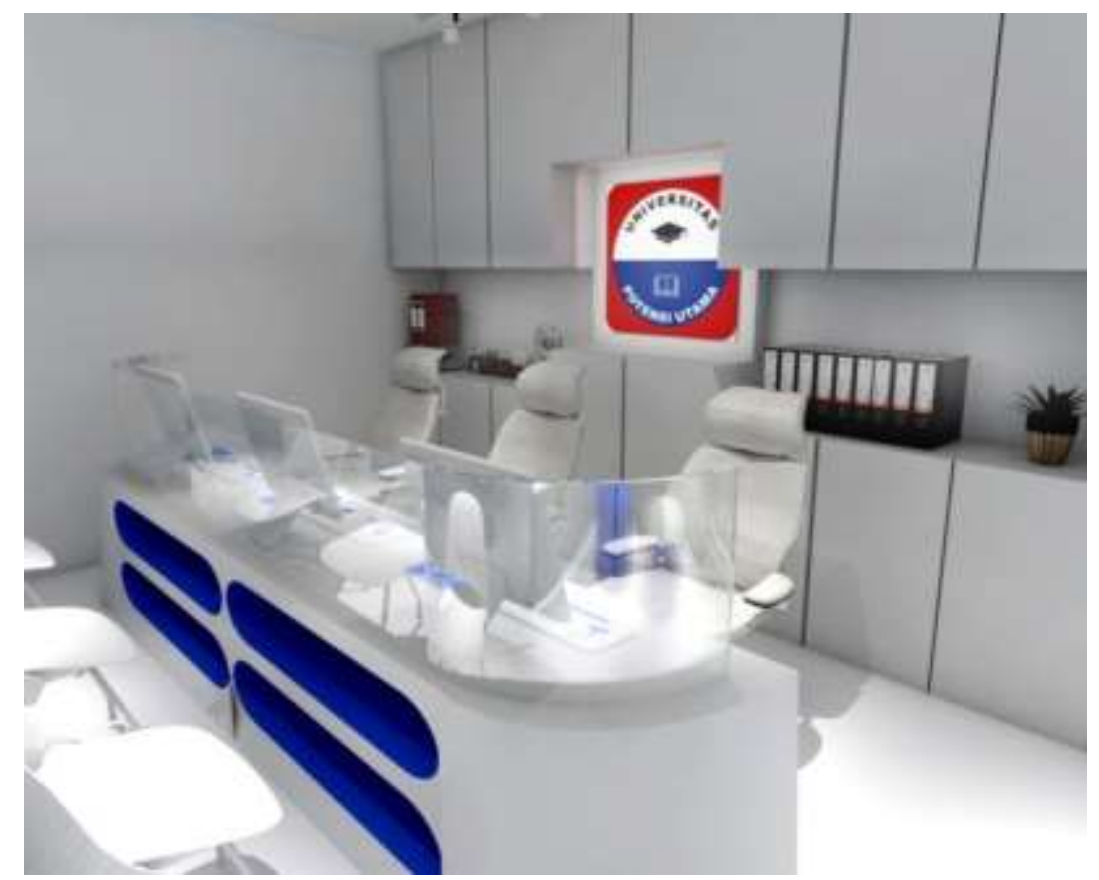

Gambar 8. Visualisasi Digital Meja Administrasi Dosen Gedung B 


\section{KESIMPULAN}

Dari keseluruhan hasil penilitian dan perancangan yang dilakukan dapat disimpulkan bahwasanya desain interior mempengaruhi suasana ruangan bagi para pegawai yang melakukan aktifitas didalam ruangan, maka dari itu perlu sekali untuk membuat suasana ruangan menjadi daya tarik tersendiri bagi para pegawai yang bekerja. Ruang Kantor Administrasi Dosen sebagai contoh suatu pengaplikasian ilmu desain interior dalam menciptakan suasana pada ruang kantor, dengan mengusung konsep futuristic yang sejalan dengan identitas dari instansi sangat memberi value yang besar dalam merepresentasikan citra instansi serta mampu mendukung budaya new normal yang akan menjadi suatu kebiasaan nantinya.

\section{DAFTAR PUSTAKA}

[1]. Andie Arief Wicaksono, Endah Trisnawati. (2014). Teori Interior.Griya Kreasi

[2]. Desain Interior Universitas Kristen Petra. 2013. JURNAL INTRA Vol. 1, No. 1, 1-7

[3]. Desain Interior Institut Teknologi Sepuluh Nopember (ITS). 2014. JURNAL SAINS DAN SENI POMITS Vol. 3, No.1, 2337-3520

[4]. Ching, Francis D.K, Ilustrasi Desain interior, (Jakarta: Erlangga, 1996)

[5]. Desain Interior Universitas Kristen Petra. 2014. JURNAL INTRA Vol. 2, No. 2, 414420

[6]. Khalkali', Ridwan. (2004). Meneleti Pengaruh Tata Ruang. Jakarta:

[7]. Panero, Julius dan Martin Zelnik, Dimensi Manusia dan Ruang Interior, (Jakarta: Erlangga, 2003)

[8]. Sunarmi, Interior Publik, (Surakarta: ISI Press, 2012)

[9]. Suptandar, J. Pamudji, "Desain Interior Pengantar Merencana Interior Untuk Mahasiswa Disain Dan Arsitektur", (Jakarta: Djambatan, 1999)

[10]. Saputra, Ryan Budhi. (2015) Teori dan Konsep Perancangan Ruang Dalam. [Online]. Tersedia: https://1219251008ketutryanbudhisaputra.wordpress.com /2015/03/10/teori-dan-konsep-perancangan-ruang-dalam/ 15 Maret 2021 